\title{
Factors affecting adoption of upland rice in Tselemti district, northern Ethiopia
}

\author{
Hadush Hagos ${ }^{1 *}$, Eric Ndemo ${ }^{2}$ and Jemal Yosuf ${ }^{2}$
}

\begin{abstract}
Background: Rice cultivation is a new practice to Tselemti district of Tigray region, Ethiopia. Adoption of rice technologies is very slow in spite of its potential in the area. This research intended to identify factors affecting adoption of rice technologies.

Methods: A multistage sampling technique was employed to select 150 sample households for this study. Descriptive statistics and inferential statistics were employed to see mean and percentage differences between adopter and non-adopter categories. Besides, binary logistic regression model was employed to identify the factors affecting adoption of rice technology.

Results: Result of the descriptive and inferential analysis showed that adopters had better farm size, livestock holding, farm income, labor availability, education level, perception on rice yield, access to credit service, contacts with extension agents, participation in off-farm activities, participation in training and field days as compared to non-adopters. Moreover, the binary logistic regression model result showed that the level of education, perception on rice yield, access to credit service, participation in off-farm activities, participation on field day and participation in training were found to positively and significantly influence the adoption decision of rice technology at 1\%, 5\% and 10\% significant level. However, market distance influences rice technology adoption negatively and significantly at $10 \%$ significant level.
\end{abstract}

Conclusions: The variables education, rice yield, access to credit, off-farm activities, market distance, participation on field day and training determine the farmers' continued adoption decision behavior of rice technology. Therefore, the adoption of rice technology should be sustained by paying attention and moving along with those variables which influenced the adoption significantly.

Keywords: Adoption, Binary logistic model, Upland rice, Tselemti district

\section{Background}

Agriculture is the mainstay of the Ethiopian economy. Although the transformation toward a more manufacturing and industrially oriented economy is well underway, the agriculture sector continues to be the most dominant aspect of the Ethiopian economy, accounting for nearly $46 \%$ of gross domestic product (GDP), $73 \%$ of employment, and nearly $80 \%$ of foreign export earnings [1]. The bulk of agricultural GDP for the period 1960-2009 had

\footnotetext{
*Correspondence: hadat2009@yahoo.com

1 Socioeconomic and Research Extension Directorate, Mekelle

Agricultural Research Center, P.O. box 492, Mekelle, Ethiopia

Full list of author information is available at the end of the article
}

come from cultivation of crops $(90 \%)$ and the remaining (10\%) from livestock production [8].

Rice has become a commodity of strategic significance in Ethiopia for domestic consumption as well as export market for economic development [3]. Besides, rice is among the target commodities that have received due emphasis, by the government, for the promotion of agricultural production. The crop is considered as the "millennium crop" for Ethiopia as it is expected to contribute for food security improvement. Rice production has brought a significant change in the livelihood of farmers and created job opportunities for a number of citizens in different areas of the country. As a result, the demand 
for improved rice technologies is increasing from time to time from different stakeholders [7].

Even if rice cultivation was not practiced in Tselemti district, it is confirmed that this crop can find appropriate ecological niches since 2007. The governmental and nongovernmental organizations have promoted improved rice varieties in order to create awareness and encourage the use of the improved varieties in the district. Demonstration and promotion have also been undertaken on the use of different improved crop management technologies such as plowing, planting, fertilizing, weeding, harvesting, post-harvest handling, and these practices are being adopted by the rice growers. The recent trends in the area and production of rice along with its high compatibility in the traditional consumption habits show that rice is becoming one of the staple foods and important for ensuring household food security in the district.

Meanwhile, the district food security and nutrition of the people depend on the amount and stability of their farm output and income. Poor choice of crops to be grown and its management system accounts for the low productivity of the district. Moreover, crops grown in the swampy soils of the district give almost no yield before rice was introduced to the district. Since it was new to the district, farmers did not fully accept the rice crop to grow on its appropriate niche. The wide range and diversified problems associated with the rice sector need to be addressed in order to make it competitive. Otherwise, the poor adoption of rice technologies by farmers would eventually lead to high cost of production with corresponding low yield. Consequently, the potential area for rice production would remain unproductive due to little motivation of farmers to grow rice.

Although rice production has increased during the last decade in Ethiopia, the country's production capacity is far below the national requirement. Disseminating improved varieties and other modern inputs to rice farmers is very important to reduce food insecurity and the rate of rice importation. Adoption of improved rice production technologies should lead to significant yield increase in rice production. As an attempt to address these problems, research institutes introduced varieties accompanied by other management practices that will produce higher yield in order to boost food security. Despite all these efforts, research findings still indicate that rural farmers in most cases find it difficult to obtain improved rice production inputs that are suitable to their local conditions [12, 13]. Reasonable proportions of the farmers are aware of the potential of rice crop production, but they have not adopted them.

The importance of farmers' adoption of new agricultural technology has long been of interest to agricultural economists, extensionists and rural development policy makers. It is believed that an effective way to increase productivity and enhance peoples' livelihoods is broadbased adoption of new farming technologies [6]. Rice area coverage in Ethiopia is still low compared to its potential [7] despite several agricultural policies and programs aimed at increasing productivities of rice implemented by the government to ensure improved food security. However, it is one thing to adopt and continue the use of the newly introduced rice crop technology; it is another thing to reject the technology adoption which is an important component that needs to be addressed in technology adoption decision process. Therefore, study on the different socioeconomic, institutional and psychological factors that influence the adoption of rice technology is useful for technology development and design of policies and strategies that foster adoption of rice technologies to cope up the current food insecurity of the district. Hence, this study was designed to identify the factors that affect adoption of rice technology in the study area to fulfill the existing knowledge gap.

\section{Methods \\ Study site description}

The study was conducted in Tselemti district of Tigray National Regional state of Ethiopia. It is found $1172 \mathrm{~km}$ far from the capital city Addis Ababa and geographically located $13^{\circ} 48^{\prime} \mathrm{N}$ latitude and $38^{\circ} 15^{\prime} \mathrm{E}$ longitude. It is bordered with Asgede Tsimbla, Welkait, Tanqua Abrgelle districts and Amhara region to the north, west, east and south, respectively. The district covers an altitude ranging from 800 to $2870 \mathrm{~m}$ above sea level. The mean annual temperature of the area is $16{ }^{\circ} \mathrm{C}$ (November-January) and $38^{\circ} \mathrm{C}$ (February-May) minimum and maximum, respectively. Some of the major crops grown in the area include sorghum, finger millet, maize, chickpea and sesame.A map indicating the study location is presented in Fig. 1.

\section{Sampling procedures and data collection}

Multistage sampling technique was employed to select the sample respondents. First, Tselemti district was purposefully selected due to its rice production potential in northwestern zone of Tigray. Secondly, from a total of 23 rural kebeles of the district, only 11 kebeles were considered for the study due to their rice production potential. The rest 12 kebeles were agro-ecologically not suitable and not experienced in rice production. From the 11 kebeles, three were randomly selected based on the relative similarity of the kebeles in the adoption of rice technology. A kebele is the smallest administrative unit in Ethiopia. Thirdly, two categories of farmers were included in the household sample; farmers who were producing rice for three or more years (adopters) and those not producing rice but have been exposed to 

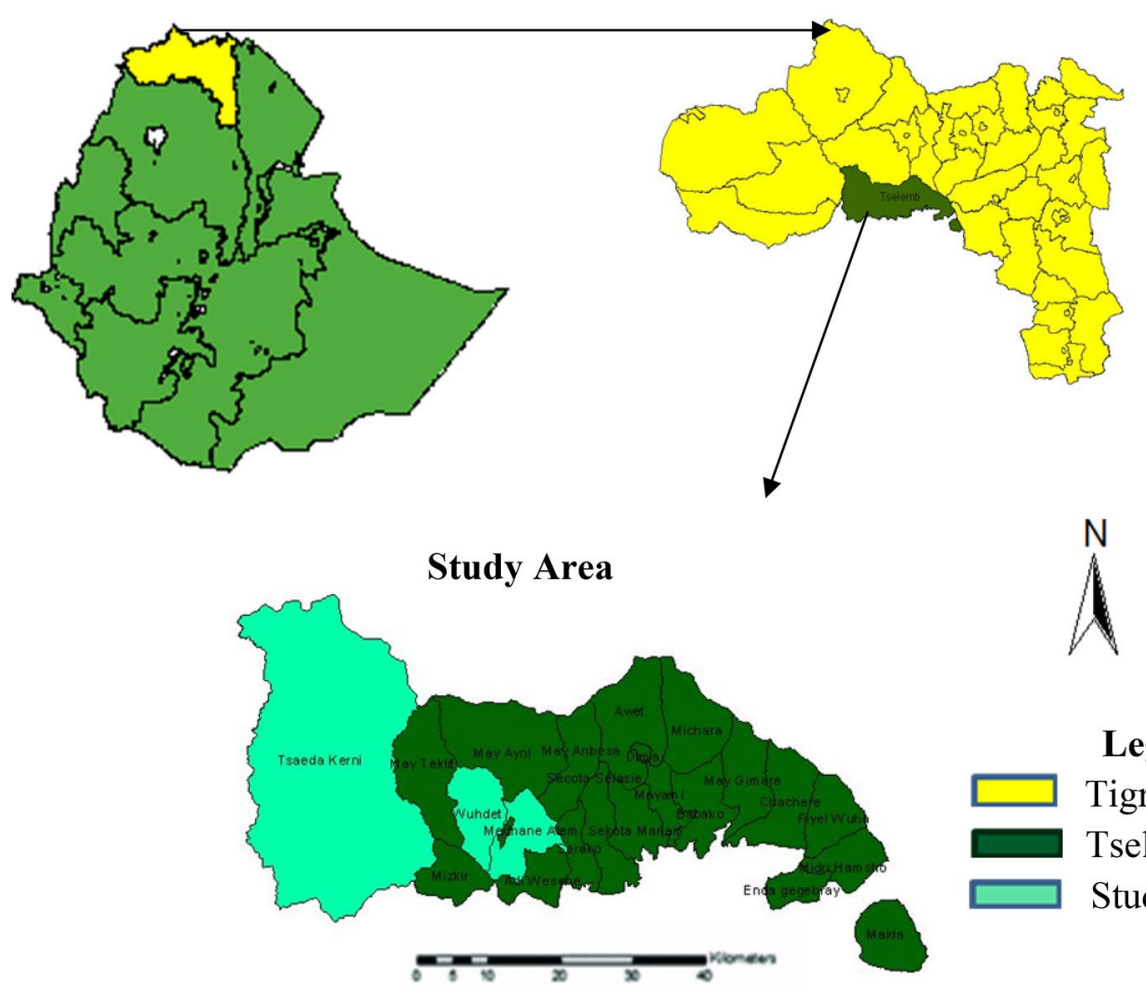

N

\section{Legend}

Tigray Region

Tselemti district

Study Kebeles

Fig. 1 Map of Tselemti district showing the study area. Source:TBoPF [16]

rice technology (non-adopters). There was a difference in rice adoption status of each sampled kebeles. Some of the kebeles were better in rice acceptance and utilization though there is a similarity in rice production potential of the area. The sample size of each category was determined by using proportional to size of the adopters and non-adopter farmers to take a representative sample for the study. Finally, of 150 households 62 adopters and 88 non-adopters were drawn with proportional to the sample size of adoption status from the three kebeles. In addition, focus group discussions (FGD) in each kebeles were conducted to supplement the data collected through individual interview.

The data collected from both primary and secondary data sources were qualitative and quantitative in nature. Semi-structured interview schedule and checklist were used as data collection tools. Prior to the interviews, the semi-structured questionnaire was pretested to control validity, and modifications were made to enhance its utility in addressing the relevant issues. The household survey was conducted in January 2015 by four trained junior researchers who administered the questionnaire to the household head or any other senior member whenever the household head was not present at the time of the interview. Moreover, Secondary data were also collected from published and unpublished documents like reports of office of agriculture and rural development, documents, research publications, journals and internet browsing.

\section{Method of data analysis}

Descriptive, inferential, and econometric model was employed to analyze the data. Descriptive statistical analysis methods were employed to discuss the result of survey using frequency, percentages, mean, and standard deviation. The Chi-square tests and $t$ test were used to see the presence of statistically significant differences and the systematic association between those who adopt and those who do not in terms of the hypothesized variables.

The logit econometric model was applied for analyzing factors influencing the adoption of rice technology. Logit model was used to determine the relative influence of various explanatory variables on the dependent variable. This model was chosen because it has an advantage that it reveals the relative influence on the probability of adoption of the technology and can predicate the probability on the extent of adoption in a proper way. 
The dependent variable in this case is dummy variable which takes the value of 1 for adopter farmers or 0 otherwise. Logit model which helps to test the determinants of adoption can mathematically be specified as follows:

$$
P_{i}=E\left(Y=1 \mid X_{i}\right)=\beta_{0}+\beta_{i} X_{i}
$$

where $Y=1$ means a given farmer participates in production.

$\mathrm{X}_{i}$ is a vector of independent variables.

$\beta_{o}$ is the constant and $\beta_{i}, i=1,2 \ldots n$ are the coefficients of the independent variables to be estimated.

$$
\begin{aligned}
& P_{i}=E\left(Y=1 \mid X_{i}\right)=\frac{1}{1+e^{-\left(\beta_{0}+\beta_{i} X_{i}\right)}} \\
& P_{i}=\frac{1}{1+e^{-z_{i}}}=\frac{e^{z}}{1+e^{z}}
\end{aligned}
$$

where $Z_{i}=\beta_{0}+\beta_{i} X_{i}$.

If $P_{i}$ is the probability of being adopter, then $\left(1-P_{i}\right)$, the probability of being non-adopter of improved rice variety is $1-P_{i}=\frac{1}{1+e^{z_{i}}}$. Therefore, we can write this equation as $\frac{p_{i}}{1-p_{i}}=\frac{1+e^{z_{i}}}{1+e^{-z_{i}}}=e^{z_{i}}$. Hence, $\frac{p_{i}}{1-p_{i}}$ is the odds

ratio in favor of adopters.

In other words, it is the ratio of the probability that a given farmer participate in production to the probability that the farmer will not participate in production. Then, if we take the natural logarithm of equations $(e)$ we obtain

$$
L_{i}=\operatorname{Ln}\left[\frac{p(i)}{1-p(i)}\right]=\ln \left[e^{\beta_{0}}+\sum_{i=1}^{m} \beta_{I} \chi_{i}\right]=Z_{(i)}
$$

If the disturbance term a is taken into account, the logit model becomes

$$
L_{i}=Z(i)=\beta_{0}+\beta_{1} X_{1}+\beta_{2} X_{2}+\beta_{3} X_{3 \ldots}+\beta_{i} X_{i}+U_{i}
$$

Therefore, $L_{i}$, which is the log of the odds ratio, is called logit or logit model [2]. Hence, the above logit model was employed to estimate the effect of the hypothesized explanatory variables on the adoption decision of farmers to use improved rice variety.

To avoid the problem of multicollinearity, both continuous and dummy variables were checked prior to executing the logit model. Different methods are often suggested to detect the existence of multicollinearity problem. Among them, variance inflation factors (VIF) technique was employed to detect multicollinearity in continuous explanatory variables [2] and the contingency coefficient (CC) for dummy variables. This analysis was carried using SPSS version 16 . The variables used in logit model are presented in Table 1.

\section{Result and discussion}

Effects of explanatory variables on adoption of improved upland rice variety

The descriptive statistics of the selected variables of the sample households examined in the study are presented in Tables 2 and 3. As shown from the Table 2, $t$ value was computed for all continuous variables and it was found statistically significant for farm size, annual farm income, livestock holding, and labor availability in adult equiva-

\begin{tabular}{|c|c|c|}
\hline Variables & Type & Measurement \\
\hline Sex of household head & Dummy & 1 male, 0 female \\
\hline Age of households head & Continuous & Age in years \\
\hline Level of education & Categorical & 1. Illiterate, 2. Read and write, 3. Primary school, 4. Secondary school and 5. College \\
\hline Farm size & Continuous & Size of land under cultivation (ha) \\
\hline Annual farm income & Continuous & Annual farm income earned (Ethiopian Birr) \\
\hline Access to credit & Dummy & 1 if the farmers has access to credit, 0 otherwise \\
\hline Livestock ownership & Continuous & Number of livestock owned in TLU \\
\hline Labor availability & Continuous & Family members in adult equivalent \\
\hline Market distance & Continuous & Distance to market in Kilometer \\
\hline Off-farm income & Dummy & 1 engagement in off-farm income activities, 0 otherwise \\
\hline Perception on rice yield & Dummy & 1 if the farmer perceives rice has better yield than other crops, 0 otherwise \\
\hline Contact with extension agents & Dummy & 1 if the farmer has contact with extension agents, 0 otherwise \\
\hline Participation in field day & Dummy & 1 if the farmer has participated in field days, 0 otherwise \\
\hline Participation in training & Dummy & 1 if the farmer has participated in training, 0 otherwise \\
\hline
\end{tabular}
lent at $1 \%$ and $5 \%$ level of significance. This implies that there was a significant difference in all these variables between the two categories (adopters and non-adopters).

Table 1 Description of explanatory variables and their measurement 
The Chi-square test was computed for the categorical and dummy variables and it was found statistically significant for educational level, contact with extension agents, credit access, off-farm income, perception on rice yield, participation on field days and participation on training at $1 \%$ and $5 \%$ significant level in these variables between the two categories.

Rice is an important component of household food intake and income in the surveyed rice grower households. Rice technology was introduced in 2007 in the study area, by Maitsebri Agricultural Research Center, which was first conducted as an observation trail of two varieties. Two nationally released rice varieties (NERICA-3 and NERICA-4) were identified and recommended to the area following the adaptation trial conducted. In addition to this, the research center released one NERICA variety (NERICA-13) nationally in 2014. NERICA rice varieties had been selected in the area for its high yielding, short maturation periods, tolerance to a biotic stresses, tolerance to lodging and high response to mineral fertilization. Owing to its success, the NERICA varieties were covered more than $95 \%$ of the area covered with rice crop. Besides, the farmers were utilized recommended inorganic fertilizer (DAP and Urea) and weed management activities.

Currently, almost all of the rice growers are food sufficient and some of them have an excess rice grain available round the year. From the total rice grower sample

Table 2 Descriptive analysis results of the continues variables

\begin{tabular}{|c|c|c|c|c|c|}
\hline \multirow[t]{2}{*}{ Variables } & \multicolumn{3}{|c|}{ Mean of adoption categories } & \multirow[t]{2}{*}{$t$ value } & \multirow[t]{2}{*}{$p$ value } \\
\hline & Adopter & Non-adopter & Total & & \\
\hline Age of the household head & 44.05 & 43.77 & 43.91 & 0.137 & 0.891 \\
\hline Farm size & 1.17 & 0.89 & 1.02 & 3.232 & $0.002^{* * *}$ \\
\hline Livestock holding & 10.65 & 7.14 & 8.89 & 4.089 & $0.000^{* * *}$ \\
\hline Market distance & 9.55 & 9.85 & 9.70 & -0.325 & 0.746 \\
\hline Annual farm income & $13,541.40$ & 8115.30 & $10,828.35$ & 3.689 & $0.000^{* * *}$ \\
\hline Labor availability & 5.19 & 4.67 & 4.93 & 2.013 & $0.046^{* *}$ \\
\hline
\end{tabular}

${ }^{* *}$ At $5 \%$ and ${ }^{* * *}$ at $1 \%$ probability level

Table 3 Descriptive analysis results of the dummy and categorical variables

\begin{tabular}{|c|c|c|c|c|c|c|}
\hline \multirow[t]{2}{*}{ Variable } & \multirow[t]{2}{*}{ Description } & \multicolumn{3}{|c|}{ Percentage between adoption categories } & \multirow[t]{2}{*}{$x^{2}$ value } & \multirow[t]{2}{*}{$p$ value } \\
\hline & & Adopter & Non-adopter & Total & & \\
\hline \multirow[t]{2}{*}{ Sex of household head } & Male & 93.6 & 89.8 & 91.3 & 0.655 & 0.418 \\
\hline & Female & 6.4 & 10.2 & 8.7 & & \\
\hline \multirow[t]{4}{*}{ Education level } & Illiterate & 37.1 & 73.9 & 58.7 & 22.874 & $0.000^{* * *}$ \\
\hline & Read and write & 14.5 & 6.8 & 10 & & \\
\hline & Primary school & 32.3 & 17 & 23.3 & & \\
\hline & Secondary school & 16.1 & 2.3 & 8 & & \\
\hline \multirow[t]{2}{*}{ Contact with extension agents } & Yes & 98.4 & 88.6 & 92.7 & 5.089 & $0.024^{* *}$ \\
\hline & No & 1.6 & 11.4 & 7.3 & & \\
\hline \multirow[t]{2}{*}{ Credit access } & Yes & 66.1 & 40.9 & 51.3 & 9.261 & $0.002^{* * *}$ \\
\hline & No & 33.9 & 59.1 & 48.7 & & \\
\hline \multirow[t]{2}{*}{ Off-farm income activities } & Yes & 37.1 & 12.5 & 22.7 & 12.554 & $0.000^{* * *}$ \\
\hline & No & 62.9 & 87.5 & 77.3 & & \\
\hline \multirow[t]{2}{*}{ Perception on rice yield } & Yes & 91.9 & 53.4 & 69.3 & 25.392 & $0.000^{* * *}$ \\
\hline & No & 8.1 & 46.6 & 30.7 & & \\
\hline \multirow[t]{2}{*}{ Participation on field days } & Yes & 72.6 & 26.1 & 45.3 & 31.660 & $0.000^{* * *}$ \\
\hline & No & 27.4 & 73.9 & 54.7 & & \\
\hline \multirow[t]{2}{*}{ Participation on training } & Yes & 66.1 & 13.6 & 35.3 & 43.865 & $0.000^{* * *}$ \\
\hline & No & 33.9 & 86.4 & 64.7 & & \\
\hline
\end{tabular}

${ }^{* *}$ At $5 \%$ and ${ }^{* * *}$ at $1 \%$ probability level 
respondents, $48 \%$ were facing to food shortage before they started to grow rice. It was due to lack of appropriate crop to their land, limited fertilizer utilization, management problem and water logging. Furthermore, the variety development and agronomic practice have been found promising to enhance production and productivity so as to improve the livelihood of small scale farmers in the region.

\section{Factors determining the adoption of upland rice technology}

The main purpose of this study was to explore the important factors that influence farmers' decisions to adopt upland rice technology. The goodness-of-fit measures were employed to check and validate that the model fits the data well. The Chi-square goodness-of-fit test statistics of the model show that the model fits the data with significance at the $1 \%$ significance level. This shows that the independent variables were relevant in explaining the farmers' decision to adopt upland rice technologies. The model predication result also shows that about $88 \%$ of the overall sample cases were correctly predicted by the model.

Out of 14 explanatory variables included in the model, seven were found to be significant in influencing the farmers' decision to adopt or not to adopt rice technologies. The remaining seven variables: sex, age, farm size, labor availability, livestock holding, farm income and contact with extension were not significant (Table 4).
That implies they do not determine the farmers' continued adoption decision behavior of rice technology.

\section{Level of education}

As expected education level of the household head had a positive and significant relationship with the probability of adoption of rice technology. The odds ratio in favor of adopting improved rice technology, other factors kept constant, increases by a factor of 2.256 for the farmer whom assumed household heads become literate than that who did not. This could be due to the fact that relatively educate farmers have more access to information and they become aware of new technology, and this awareness enhances the adoption of technologies. This result is consistent with finding of Umeh and Chukwu [20], Tiamiyu et al. [17], Rahman and Bulbul [14] and Leake and Adam [5] which suggested that the more educated the farmer was, the more likely to adopt new technology. On the contrary, the negative influence of education was also observed in other study by Tura et al. [19] which justifies households headed by literates were relatively less likely to adopt improved maize varieties in Central Ethiopia. This was due to the fact that the relatively more educated household heads were youngsters and the land ownership among the youth was minimal.

\section{Perception on rice yield}

Farmers' perception about the yield of rice was found to-influence adoption of rice technology positively and

\section{Table 4 The maximum likelihood estimation of the binary logit model}

\begin{tabular}{|c|c|c|c|c|c|c|}
\hline No. & Variable & $B$ value & SE & Wald & Sig. & Odds ratio \\
\hline 1 & Age of the household head & 0.035 & 0.027 & 1.632 & 0.201 & 1.035 \\
\hline 2 & Sex of the household head & -0.513 & 1.029 & 0.249 & 0.618 & 0.599 \\
\hline 3 & Level of education & 0.814 & 0.333 & 5.980 & $0.014^{* *}$ & 2.256 \\
\hline 4 & Farm size & 0.166 & 0.602 & 0.076 & 0.783 & 1.181 \\
\hline 5 & Livestock holding & 0.032 & 0.069 & 0.211 & 0.646 & 1.032 \\
\hline 6 & Perception on rice yield & 2.468 & 0.750 & 10.822 & $0.001^{* * *}$ & 11.797 \\
\hline 7 & Off-farm income & 1.113 & 0.643 & 2.997 & $0.083^{*}$ & 3.044 \\
\hline 8 & Access to credit & 0.981 & 0.515 & 3.627 & $0.057^{*}$ & 2.666 \\
\hline 9 & Market distance & -0.084 & 0.050 & 2.838 & $0.092^{*}$ & 0.919 \\
\hline 10 & Contact with extension agent & 0.407 & 1.313 & 0.096 & 0.757 & 1.502 \\
\hline 11 & Participation on field days & 1.755 & 0.585 & 8.996 & $0.003^{* * *}$ & 5.784 \\
\hline 12 & Participation on training & 1.287 & 0.569 & 5.127 & $0.024^{* *}$ & 3.624 \\
\hline 13 & Annual farm income & 0.000 & 0.0001 & 1.580 & 0.209 & 1.000 \\
\hline 14 & Labor availability & 0.087 & 0.201 & 0.189 & 0.664 & 1.091 \\
\hline 15 & Constant & -8.035 & 2.397 & 11.239 & $0.001^{* * *}$ & 0.000 \\
\hline$x^{2}$ value & & & $100.541^{* * *}$ & & & \\
\hline$-2 \log$ likelihood & & & 102.873 & & & \\
\hline Overall model predictions & & & $88 \%$ & & & \\
\hline
\end{tabular}

***, ${ }^{* *}$ and ${ }^{*}$ significant at $1 \%, 5 \%$ and $10 \%$ significant level, respectively 
significantly at less than $1 \%$ significance level. Farmers' perception of the superiority on yield of rice crop compared to other crops in the area creates interest to adopt rice technology. The odds ratio, other things kept constant, implies that the probability of adopting rice technology increases by a factor of 11.797 as the perception of yield benefit relative to other crops increases. A similar result was reported by Langyintuo and Mungoma [4] and Wen-chi et al. [21] that imply yield potential plays a crucial role in choosing a given variety. Therefore, the probability of adoption of improved technologies would increase once a farmer perceives that the yield potential of the given crop was higher than that of the existing one.

\section{Off-farm activities}

The engagement in an off-farm income activities was found to have positive and significant influence on the adoption of upland rice. The odds ratio, other things kept constant, implies that the probability of adopting rice technology increases by a factor of 3.044 as the farmer's engagement in off-farm source of income increase by one unit. This could be associated with the farmers opportunity of using money from off-farm activities for purchasing of inputs that enable them to adopt rice technology. This was consistent with the findings of Tura et al. [19] and Olalekan and Simeon [11] that shows the possibility of using money from off-farm activities for purchasing of inputs necessary to continue growing improved varieties.

\section{Access to credit service}

As the model result indicates, the variable access to credit had positively and significantly influenced the likelihood of adoption of rice technology. From this result, it can be stated that those farmers who have access to formal credit, from agricultural office and cooperatives were more probable to adopt rice technology than those who have no access to formal credit. The odds ratio indicated in the model with regard to credit implies that, another thing being held constant, the odds ratio in favor of adopting rice technology increases by a factor of 2.666 as farmers get access to credit. Earlier studies by Ogutu and Obare [10] and Leake and Adam [5] also indicated that credit availability significantly affects the adoption of improved technologies and the quantity of inputs farmers apply.

\section{Market distance}

The variable market distance affects the adoption decision of farmers negatively and significantly at $10 \%$ level of significance. The result of the odds ratio indicated that as the market distance increases, the logs of odds ratio in favor of households' adoption of rice technology decrease by 0.919 . This implies that farmers who are distant from the input and output market have less likelihood to adopt the improved upland rice technology. The study by Solomon et al. [15], Yemane [22] and Olalekan and Simeon [11] were consistent with this result; that shows distance from the nearest market affects adoption of improved agricultural technology negatively and significantly. It also indicates that the shorter the distance from the household to the nearest market, the higher the probability of adopting new technology.

Rice crop was matched with the farmer's needs and field realities of the area. Farmers do not operate their rice farm on a large scale in isolation, but within the wider market system. The farmers were able to produce surplus paddy rice in their farms. However, most of the rice producer farmers respond that there were market problems in their nearest place. The major rice marketing difficulties were related to non-availability of market, a small number of market actors, low quality product that can meet consumer demand, and absence of rice polisher. As a result, a major portion of the total production was consumed and very little sold in the local market for consumers and as a seed formally and informally.

\section{Participation on field days}

It was found that exposure to information in relation to attending field days had positively and significantly influenced the probability of adoption of rice technology at less than $1 \%$ significant level. When farmers practically observe a new practice they could weigh the advantage and disadvantages of the new technology. This can facilitate adoption and helps them to implement the new technology properly in their own situation. Another thing held constant, the odds ratio of the variable attending field days implies that as farmers' exposure to agricultural information through field day increases, the odds ratio in favor of adopting improved rice technology increases by a factor of 5.784. This result goes along with the study done by Mustapha et al. [9] and Yemane [22] that revealed exposure to information due to participation in field days had a positive and significant influence on the probability of adoption of improved upland rice variety.

\section{Training participation}

Training was important for acquiring information, knowledge and developing abilities or attitudes, which result in greater competence in the performance of a work. It was found that participation in training had positively and significantly influenced the probability of adoption of rice technology at less than 5\% significant level. The more the opportunity to participate in rice technology related training programs had increased farmers' adoption of rice technologies. This implies that if the households participated in training, the logs of 
odds ratio in favor of households' adoption of rice technology increased by a factor of 3.624. A study by Tsado et al. [18] showed the responses of the participants on the training and adoption of the improved rice package had most impacted their lives. The farmers have received training and experience sharing on rice variety development, agronomic practices, post-harvest handling and utilization on different food recipes. The wereda office of agriculture and rural development, Agricultural Research and NGOs were the main rice training and experience sharing providers in the area.

\section{Conclusion and policy implication}

Descriptive statistical analysis results show that adopters of rice technologies were better on education level, access to farmland, family labor force, livestock ownership, earning annual farm income and perception of rice yield. In addition to this, adopters of rice technology had participated more in off-farm activities, access to credit, contact with extension agents, rice related training and field days than the non-adopters.

The econometric regression binary logit model result indicated that level of education, perception on rice yield, access to credit service, participation in off-farm activities, participation on field day and participation in training influencing adoption positively and significantly. Furthermore, market distance influences rice technology adoption negatively and significantly. However, the remaining seven explanatory variables: sex of the household, age, farm size, labor availability, livestock holding, farm income and contact with extension agents were not significant. This implies they do not determine the farmers' sustained adoption decision behavior of rice technology in the study area.

This suggested that, in line with the formal education, focus should be given for adult and continues the training program to bring a change in the adoption of new technologies. Strengthening of rural cooperatives which can deliver inputs and credit on reliable market price should be enhanced. The quantity and quality of rice produced at the farm level affected marketable supply, household income, and its contribution to food security and self-sufficiency. Thus, all stakeholders, especially the agricultural extension service, need to carry out more aggressive promotion of the improved rice technologies through appropriate mechanisms in input delivery, processing facilities and creating market opportunities. Proper attention is also needed for the development of income generating activities through constructing rural infrastructures in order to increase the participation of farmers in off-farm income activities. Moreover, frequent training of the rice farmers in the study area should be given attention, so that the farmers can obtain optimum yield from the adoption of improved rice varieties and attract other farmers. The participation of farmer in field days has to be strengthened so as to improve farmers' access to practical information and extension advice to adopt and expand the new innovation in a sustainable way.

\section{Authors' contributions}

$\mathrm{HH}$ carried out the study, worked out almost all of the technical details, and performed the numerical calculations for the suggested experiment. EN and $J Y$ analyzed the data and wrote the manuscript. EN contributed to the design and implementation of the research, to the analysis of the results and to the writing of the manuscript. JY devised the proposal, the main conceptual ideas and proof outline. All authors read and approved the final manuscript.

\section{Author details}

1 Socioeconomic and Research Extension Directorate, Mekelle Agricultural Research Center, P.O. box 492, Mekelle, Ethiopia. ${ }^{2}$ Department of Rural Development and Agricultural Extension, Haramaya University, Tselemti, Ethiopia.

\section{Acknowledgements}

The authors would like to thank Tigray Agricultural Research Institute for financing the research work. Similarly, we are grateful to the respondent farmers who have spent their precious time to respond attentively to questionnaire. Moreover, the agricultural office of the district had direct and indirect contribution for the successfulness of the survey work.

\section{Competing interests}

The authors declare that they have no competing interests.

\section{Availability of data and materials}

It is possible to access the data on personnel request from the principal investigator.

\section{Funding}

No funding was received for this publication.

\section{Publisher's Note}

Springer Nature remains neutral with regard to jurisdictional claims in published maps and institutional affiliations.

Received: 8 December 2017 Accepted: 3 August 2018

Published online: 16 August 2018

\section{References}

1. ATA (Agricultural Transformation Agency). Transforming agriculture in Ethiopia. 2014; Annual Report 2013/2014, Addis Ababa, Ethiopia.

2. Gujarati DN. Basic econometrics. 4th ed. New York: McGraw-Hill; 2004

3. Hegde S, Hegde V. Assessment of global rice production and export opportunity for economic development in Ethiopia. Int J Sci Res. 2013;2(6):2319-7064.

4. Langyintuo A, Mungoma C. The effect of household wealth on the adoption of improved maize varieties in Zambia. Food Policy. 2008;33(6):550-9.

5. Leake G, Adam B. Factors determining allocation of land for improved wheat variety by smallholder farmers of northern Ethiopia. J Dev Agric Econ. 2015;7(3):105-12.

6. Minten B, Barret BC. Agricultural technology, productivity, and poverty in Madagascar. World Dev. 2008;36(35):797-822.

7. MoARD (Ministry of Agriculture and Rural Development). National Rice Research and Development Strategy. Ministry of Agriculture and Rural Development, the Federal Democratic Republic of Ethiopia. Addis Ababa, Ethiopia, 2010.

8. MoFED (Ministry of Finance and Economic Development). National income accounts, Addis Ababa, Ethiopia. www.mofeddatabase.com. Accessed 4 Feb 2010. 
9. Mustapha SB, Makinta AA, Zongoma BA, Iwan AS. Socioeconomic factors affecting adoption of soya-bean production technologies in Takum local government area of Taraba State, Nigeria. Asian J Agric Rural Dev. 2012;2(2):4-6.

10. Ogutu WN, Obare GA. Crop choice and adoption of sustainable agricultural intensification practices in Kenya. Adoption pathways project discussion paper 10. Egerton University, Kenya; 2015.

11. Olalekan AW, Simeon BA. Discontinued use of improved maize varieties in Osun state, Nigeria. J Dev Agric Econ. 2015;7(3):85-91.

12. Onyeneke RU. Determinants of Adoption of Improved Technologies in Rice Production in Imo State, Nigeria. Afr J Agricultural Res. 2017;12(11):888-96.

13. Osanyinlusi Ol, Adenegan KO. The determinants of rice farmers' productivity in Ekiti State, Nigeria. Greener J Agric Sci. 2016;6(2):049-58.

14. Rahman MR, Bulbul SH. Adoption of water saving irrigation techniques for sustainable rice production in Bangladesh. Environ Ecol Res. 2015;3(1):1-8

15. Solomon A, Bekele S, Franklin S, Mekbib G. Agricultural technology adoption, seed access constraints and commercialization in Ethiopia. J Dev Agric Econ. 2011;3(9):436-47.
16. TBoPF (Tigray Bureau of Planning and finance). Atlas of Tigray. Mekelle, Ethiopia; 2014

17. Tiamiyu SA, Usman A, Ugalahi UB. Adoption of on-farm and postharvest rice quality enhancing technologies in Nigeria. Tropicultura. 2014;32(2):67-72.

18. Tsado JH, Ojo MA, Ajayi OJ. Impact of training the trainers' programme on rice farmers' income and welfare in North Central, Nigeria. J Adv Agric Technol. 2014;1 (2):157-60.

19. Tura M, Aredo D, Tsegaye W, Rovere RL, Tesfahun G, Mwangi W, Mwabu G. Adoption and continued use of improved maize seeds: case study of Central Ethiopia. Afr J Agric Res. 2010;5(17):2350-8.

20. Umeh GN, Chukwu VA. Determinants of adoption of improved rice production technologies in Ebonyi state of Nigeria. Int J Food Agric Vet Sci. 2013;3(3):126-33.

21. Wen-chi H, Ghimire R, Shrestha R. Factors affecting adoption of improved rice varieties among rural farm households in central Nepal. Rice Sci. 2015;22(1):35-43.

22. Yemane A. Determinants of adoption of upland rice varieties in Fogera district, Ethiopia. J Agric Ext Rural Dev. 2014;8(12):332-8.
Ready to submit your research? Choose BMC and benefit from:

- fast, convenient online submission

- thorough peer review by experienced researchers in your field

- rapid publication on acceptance

- support for research data, including large and complex data types

- gold Open Access which fosters wider collaboration and increased citations

- maximum visibility for your research: over 100M website views per year

At BMC, research is always in progress.

Learn more biomedcentral.com/submissions 